\title{
大型物流施設の建替え工事にお ける既存杭利用と調查
}

\section{INVESTIGATION OF EXISTING PILES USED IN RECONSTRUCTING LARGE LOGISTICS WAREHOUSE}

勝二理智 - $* 1$ 藤森健史 $-* 1$

キーワード :

既存杭，杭の弾性波探査試験，圧縮強度，中性化，杭長

Keywords:

Existing pile, Pile integrity test, Compression strength, Neutralization, Pile length
Michito SHOJI_— $* 1 \quad$ Takeshi FUJIMORI — $* 1$

In reconstructing the large logistics warehouse with using existing piles, the piles were investigated. The pile diameter and reinforcement arrangement were as designed, and almost all the piles had no crack. The soundness evaluation by the author's method was equivalent to that of conventional method. The compressive strength was larger than the designed value, and the neutralization depth was smaller than the designed cover thickness. The embedment in the bearing layer was confirmed by the comparison between the core boring through the pile and the standard penetration test. The magnetic exploration was effective on the evaluation of pile length.

\section{1.はじめに}

建物の建替え時に既存杭を利用することができれば，環境負荷の 低減やコスト削減，工期短縮の効果を期待できる。利用にあたって は既存杭の性能や品質を確認寸る必要があり, 杭の健全性・耐久性・ 支持力について調查することが一般的である。既存杭利用に関する 手引き ${ }^{1)}$ やマニアル ${ }^{2)}$ が発刊されて十数年経過したが，今なお， そこで示された前記 3 項目の調查を実施するに留まる例が多い。ま た, その調查方法についても, 建物解体中の杭調查に関寸る報告 ${ }^{3)}$, 健全性を調べる杭の弾性波探查試験に関する筆者らの研究 ${ }^{4)}$ 等ある が，目立った進展は見られない。

今回, 某大型物流施設の建替え工事において, 既存杭を利用して 建物を新築する計画となった。そこで，既存杭の品質確認を高度化 することを目的として，健全性評価に筆者らの提案手法を試行する とともに，現行の文献 1),2)では項目として挙がっていない杭の支
持層到達についても調査した。同時に，耐久性調査により既存杭の 経年劣化に関する知見も得られたため，ここに報告する。

\section{表 1 建物概要}

\begin{tabular}{|c|c|c|}
\hline 項目 & 新築建物 & 既存建物 \\
\hline 建物階数 & 地上6階 & 地上7階 \\
\hline 延床面積 & $171,000 \mathrm{~m}^{2}$ & $174,000 \mathrm{~m}^{2}$ \\
\hline 建物用途 & 倉庫業を営む倉庫、事務所 & 同左 \\
\hline 竣工年 & 2017年 & 1973年 \\
\hline 構造形式 & 柱 $\mathrm{SRC}$ - 梁 $\mathrm{S}$ 造, 基礎免震 & RC造, 一部SRC造 \\
\hline 基礎形式 & $\begin{array}{c}\text { 既製コンクリート杭 (PRC杭, PHC杭) } \\
500 \sim 1200 \phi, \text { 杭長 } 19 \sim 35 \mathrm{~m} \\
\text { 場所打ちコンクリート杭 (既存杭利用) } \\
1200 \phi, \text { 杭長 } 31 \mathrm{~m}\end{array}$ & $\begin{array}{c}\text { 場所打ちコンクリート杭 } \\
1200 \sim 1400 \phi \text {, 杭長 } 19 \sim 31 \mathrm{~m} \\
\text { 設計基準強度 } 18 \mathrm{~N} / \mathrm{mm}^{2}\end{array}$ \\
\hline
\end{tabular}

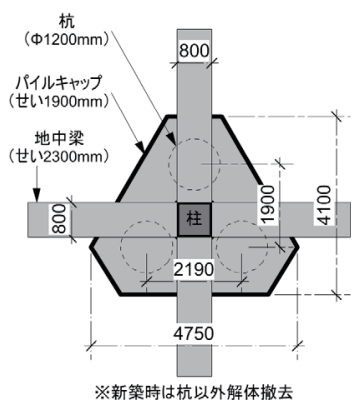

図 2 既存建物の杭伏図 


\section{2. 構造計画}

建物概要を表 1 , 新築建物の杭伏図を図 1 , 既存建物の杭伏図を図 2 ，士質柱状図と杭深度の関係を図 3〜 4 に示寸。新築建物は，既製 コンクリート杭で支持された地上 6 階の柱 SRC一梁 S 造の基礎免震 建物である。杭支持層の深度が敷地の南北で異なっており, 杭基礎 の水平剛性のバランスを取ることが構造的な課題であった。水平剛 性確保のため, 敷地南側に新設杭を増打ちすることも考えられたが, 環境配慮・コス卜低減・既存杭の利用促進の点から, 敷地に存在す る既存杭 84 本を利用する計画とした。既存杭はアースドリル工法で 築造された場所打ちコンクリート杭であり, 直径 $1200 \mathrm{~mm}$ の直杭であ る。杭頭深度は GL-1. $2 \mathrm{~m}$, 杭先端深度は GL-32m, 支持層は細砂層で ある。杭コンクリートの設計基準強度は $18 \mathrm{~N} / \mathrm{mm}^{2}$ である。既存建物 ではパイルキャップ 1 基に既存杭 3 本が接合した基礎形式であった ため, 新築時の既存杭利用にあたっては, パイルキャップを解体し 杭頭を処理した後に, マットスラブを構築した。既存杭頭での負担 曲げモーメントを低減するため, 杭頭半剛接合工法を採用した。

\section{3. 既存杭調査計画}

既存杭利用にあたり, 表 2 に示寸杭の健全性, 耐久性および支持 層到達の調查を実施した。調查方法と調查数量については, 文献 1)，2）を参考に計画した。健全性調査は利用する杭全数を対象に，耐 久性調査は利用寸る杭から適切にサンプリングして, それぞれ実施 した。支持層到達を確認する調查は前記文献 1)，2）では挙がってい ないが，杭の品質確認にあたり重要と考えて実施した。調査は主に 建物解体後に実施したが，既存杭利用の可否をプロジェクト早期に
判断するため, 建物解体前に, 利用する杭本数の 1 割を目安に, 弾 性波探查試験と圧縮強度試験を先行して実施した。なお本件では, 既存杭の施工記録は得られず, 過去の地震被害は確認されなかった。

杭の健全性について, 杭径と配筋状況は杭頭目視, 杭のひび割れ 有無は弾性波探查試験により確認した。杭頭目視調查は建物解体に より露出した杭頭で実施し, 杭径 (東西, 南北, 45 度方向), 配筋状 況 (鉄筋種別, 鉄筋本数, かぶり厚さ) を確認した。弾性波探查試験 は, 杭頭をハンマで軽打し低ひずみの弾性波を発生させ, 杭体から の反射波を杭頭に取り付けたセンサで測定し, ひび割れの有無や位 置を推定する技術である。本調査では露出した杭頭で試験を実施し たが, 建物解体前に調查した杭については，1 階床スラブから杭頭 まで鉛直に削孔した孔底で試験を実施した。試験結果については, 従来の判定基準 ${ }^{2)}$, 5) に基づき評価するとともに, 図 5 に示す筆者ら の提案手法 ${ }^{4)}$ による評価も併せて実施した。

杭の耐久性について, 杭コンクリートの圧縮強度と中性化深さ, 杭主筋の機械的性質 (降伏点, 引張強さ, 伸び) を確認した。圧縮強 度については, 弾性波探査試験用に杭頭部を削孔した鉛直コアから 24 供試体, 後述する杭長確認のため杭全長を削孔した鉛直コアから 19 供試体を採取し, 試験を実施した。中性化深さについては, 露出 した杭頭で杭側面から水平に削孔して 24 供試体を採取し, 試験を実 施した。試験では, 供試体の割裂面にフェノールフタレイン溶液を 噴霧し, 赤紫色に変色した境界深さを 1 供試体あたり 5 箇所で測定 した。なお, 圧縮強度試験と中性化試験で用いた供試体の寸法は, 直径 $100 \mathrm{~mm}$, 高さ $200 \mathrm{~mm}$ である。鉄筋引張試験については, 露出し た杭頭で長さ $650 \mathrm{~mm}$ 程度の杭主筋 24 本を採取し, 試験を実施した。
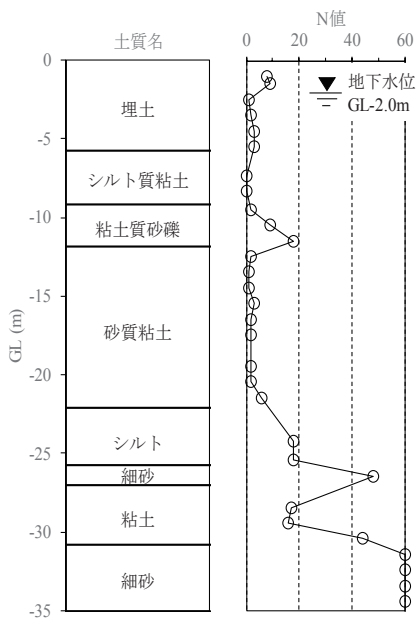

図 3 土質柱状図 (No. 2) と既存杭深度
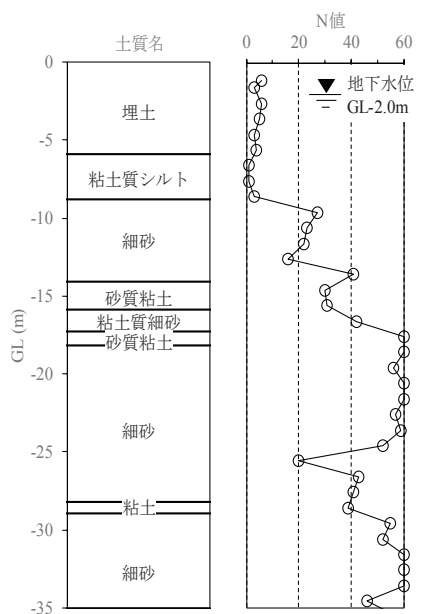

図 4 土質柱状図 (No. 3) と新設杭深度

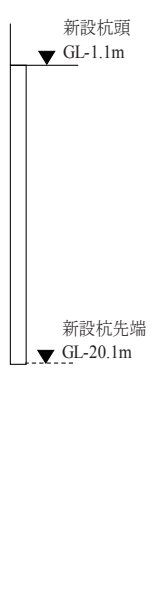

図 5

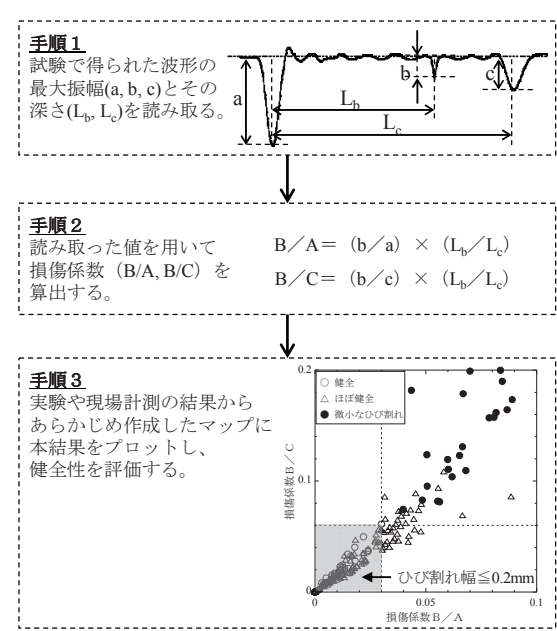

5 弾性波探査試験に基づく杭健全性評価法 ${ }^{4)}$

表 2 調査方法と調査数量

\begin{tabular}{|c|c|c|c|c|}
\hline 分類 & 調査方法 & 確認項目 & 数量 & 調査概要 \\
\hline \multirow{2}{*}{ 健全性 } & 杭頭目視調査 & 杭径, 配筋状況 & 84 本 & 測量, 目視観察 \\
\hline & 杭の弾性波探査試験 & 杭のひび割れ有無 & 84本 & 弾性波の反射性状から健全性を推定 \\
\hline \multirow{3}{*}{ 耐久性 } & コンクリート圧縮強度試験 & 杭コンクリートの圧縮強度 & 9本 & 圧縮強度試験方法 (JIS A 1107) \\
\hline & コンクリート中性化試験 & 杭コンクリートの中性化深さ & 8 本 & コンクリートの中性化深さの測定方法 (JIS A 1152) \\
\hline & 鉄筋引張試験 & 杭主筋の機械的性質 & 6本 & 金属材料引張試験方法 (JIS Z 2241) \\
\hline \multirow{3}{*}{$\begin{array}{l}\text { 支持層 } \text { 到達 }\end{array}$} & 杭全長コアボーリング & 施工杭長 & 1本 & 杭体の貫通ボーリング \\
\hline & 磁気探査 & 施工杭長 & 1本 & 杭鉄筋による磁場の変化の測定 \\
\hline & 標準貫入試験 & 杭支持層の深度 & 2地点 & 標準貫入試験方法 (JIS A 1219) \\
\hline
\end{tabular}


杭の支持層到達については, 施工された杭の長さと杭支持層の深 度を比較することで確認した。施工杭長については, 杭全長コアボ ーリングにより杭体を貫通して確認し, 同時に得られるコア試料は 前記の通り圧縮強度試験に供した。また, 杭全長コアボーリングに 比べ簡易性が高く, 高精度を期待できる磁気探査も併せて実施した。 磁気探査は，杭鉄筋による磁場の変化を測定して杭長を推定する技 術であり, ここでは磁気傾度計を用いた ${ }^{6)}$ 。本調查では, 対象の杭 から $1 \mathrm{~m}$ 離れた地点 (ほかの近くの杭からは $3 \mathrm{~m}$ 程度離れている) で鉛 直に掘削し, 孔壁保護のため塩ビ管を建込み, センサを孔内に挿入 し, 杭頭から杭先端より $5 \mathrm{~m}$ 深い位置まで連続的に測定した。杭支持 層の深度については, 磁気探査用の試験孔と貫通後の杭直下で標準 貫入試験を実施して確認した。

\section{4. 既存杭調査結果}

\section{1 杭の健全性}

測定した杭径の度数分布を図 6 に示す。ここで, $\mathrm{N}$ : 供試体数, $\mu$ : 平均值, $\sigma$ : 標準偏差である。図より, 測定值の大半は $1.25 \mathrm{~m} \sim 1.45 \mathrm{~m}$ の範囲に分布しており, 平均值は $1.37 \mathrm{~m}$, 標準偏差は $0.07 \mathrm{~m}$ であり, 設計径 $1.2 \mathrm{~m}$ を上回る值である。また杭頭目視により, 杭 84 本中 82 本の配筋状況は設計通りであることを確認できた。

弾性波探查試験で得られる波形には, 杭頭打撃と杭先端反射によ る振幅が生じるが, ひび割れのような断面縮小部があれば, その杭 体からの反射振幅も生じる。従来の判定基準 ${ }^{2)}$,5) では 3 つに大別さ

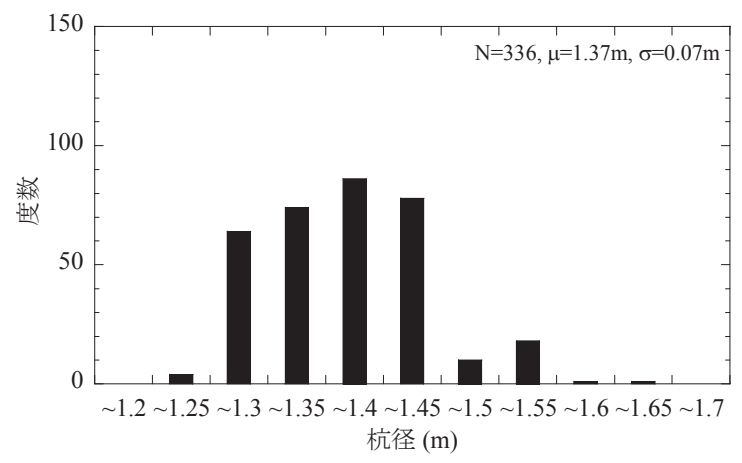

図 6 杭径の度数分布
れ，杭頭打撃と杭先端反射がある場合は “健全性が高いと考えられ

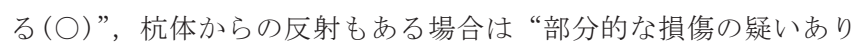
$(\triangle)$ ”, 杭先端反射が無く杭頭打撃の重複反射のみ見られる場合は “杭の全断面におよぶ損傷の疑いあり $(\times)$ ”となる。この判定基準 により評価した結果, ○の杭は 75 本, $\triangle$ の杭は 9 本であった。それ らの代表的な 1 本の試験波形を図 7 に示す。図の縦軸は振幅, 横軸 は打撃入力した杭頭からの深度であり, 弾性波の伝播速度は文献 2) より $3800 \mathrm{~m} / \mathrm{s}$ とした。図 7 (a) の波形には杭頭打撃 (深度 $0 \mathrm{~m}$ ) と杭先端 反射 (深度 $31 \mathrm{~m}$ ) の振幅が生じ, その間に負側に有意な振幅が生じて いないが, 図 7 (b) の波形には深度 $5 \mathrm{~m}$ 位置で負側に振幅が生じてい る。続いて, 提案手法による評価結果を図 8 亿示す。図の縦軸と横 軸は, 杭のひび割れの大きさを示寸指標(損傷係数)であり, 破線で 囲まれた図の左下の範囲は, ひび割れ幅が $0.2 \mathrm{~mm}$ 以下の範囲である。 図中には, 文献 4) で検討した実験や現場計測の結果 (杭径 $2 \mathrm{~m}$, 杭長 $35 \mathrm{~m}$ までの場所打ちコンクリート杭を対象)を併せて示している。図 より, 左下の範囲に分布する杭は 75 本, その範囲外に分布する杭は 9 本であり, 前述した従来の判定と等しい結果を与えている。また, 既往の調查結果に比べやや左上に分布する傾向があり, 文献 4) で指 摘したように波形の振幅の増幅率によるもので評価には影響しない と考えられるが, 今後の検討課題としたい。

このように, 従来手法と提案手法の双方で損傷の疑いがあると評 価した 9 本の杭について, さらに考察する。この 9 本の波形には, 図 7 (b) で示したように杭頭打撃や杭先端反射以外の反射がみられ, 深い位置 (深度 $21 \mathrm{~m}$ ) に反射がある杭が 1 本, 浅い位置 (深度 $5 \sim 7 \mathrm{~m}$ ) に反射がある杭が 8 本であった。前者については, 損傷または土塊 の介在による断面欠損の可能性が考えられる。後者についても同様 の可能性はあるが, 杭体からの反射の深度が揃っていること, 対象 の杭が偏って存在せずに杭範囲全般に分布していることから, 築造 時に用いた表層ケーシング下端での断面縮小の可能性が高いと判断 した。文献 7)によれば，表層ケーシングには次の特徴がある；1）ケ ーシング径は杭径より 100～200mm 程度大きいものを使用する。2） ケーシング長さは通常 $2 \sim 4 \mathrm{~m}$ 程度のものが用いられるが, 表層部の 土質が埋戻し土や砂のように崩壊性が高い場合には, その層の下端 面から $0.5 \mathrm{~m}$ 程度根入れできる長さのものが良い。ここで, 土質柱状

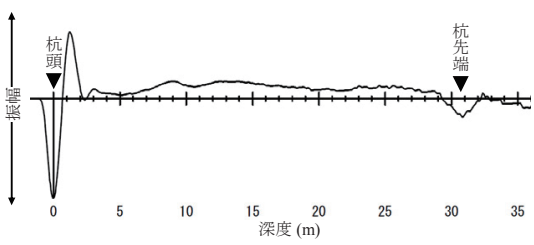

（a）“健全性が高いと考えられる”杭

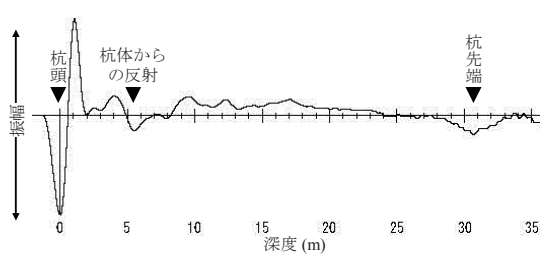

（b）“部分的な損傷の疑いあり”の杭 ※ただし損傷ではなくケーシングの影響と考えられる。 図 7 弾性波探査試験波形

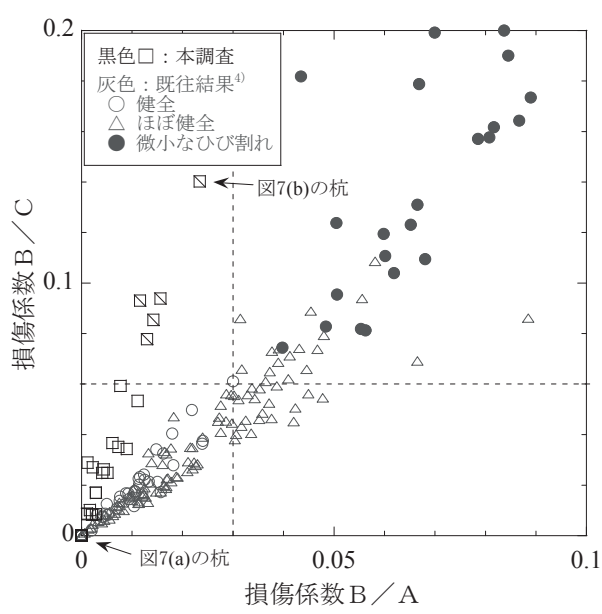

(a) $\mathrm{B} / \mathrm{A}<0.1$

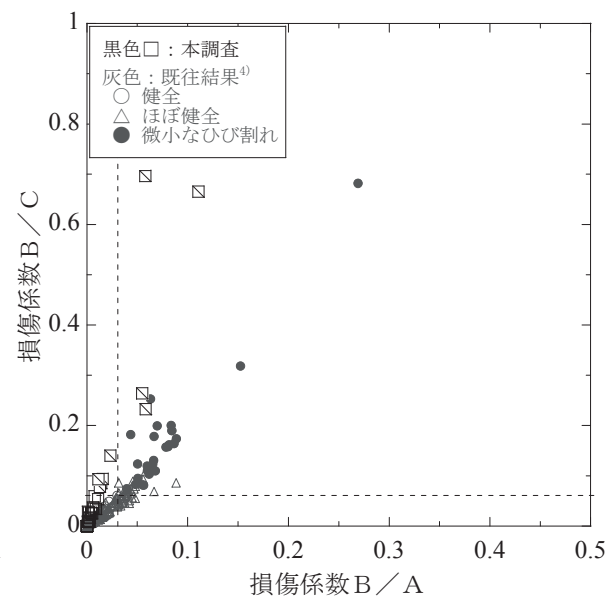

(b) $\mathrm{B} / \mathrm{A}<0.5$

図 8 提案手法による杭健全性評価 
図(図 3,4)より表層の埋土層厚は $6 \mathrm{~m}$ 程度であり, 杭築造にあたって は, その下の粘土層・シルト層にケーシングを根入れしたと推察さ れる。ただし, ケーシングによる断面縮小が緩やかな場合は, 明確 な反射波を得られないため ${ }^{5), 8)}$, 大多数の杭では反応が潜在化した と考えられる。

以上より, 杭 84 本中 81 本が健全であり, 配筋状況から 2 本, 弾性波探查試験から 1 本が健全でない可能性がある結果を得た。こ れらの状況から, 安全をみて 81 本を有効とし, 当初設計にて性能 を確保できることを確認した。なお，この結果による設計変更や杭 の再施工は生じなかった。

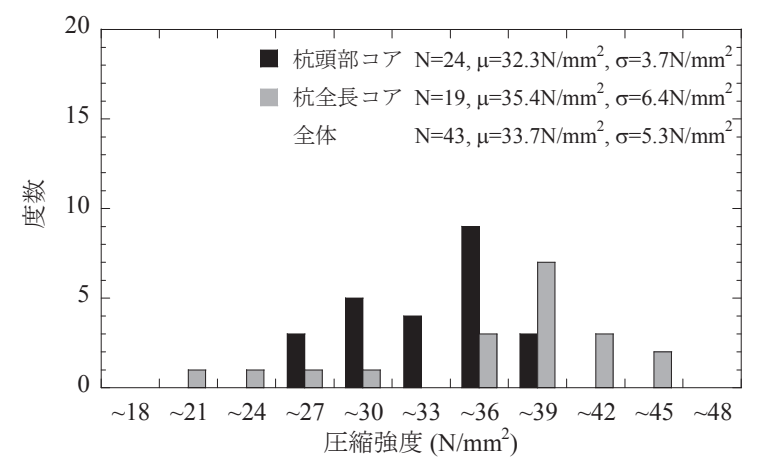

図 9 圧縮強度の度数分布

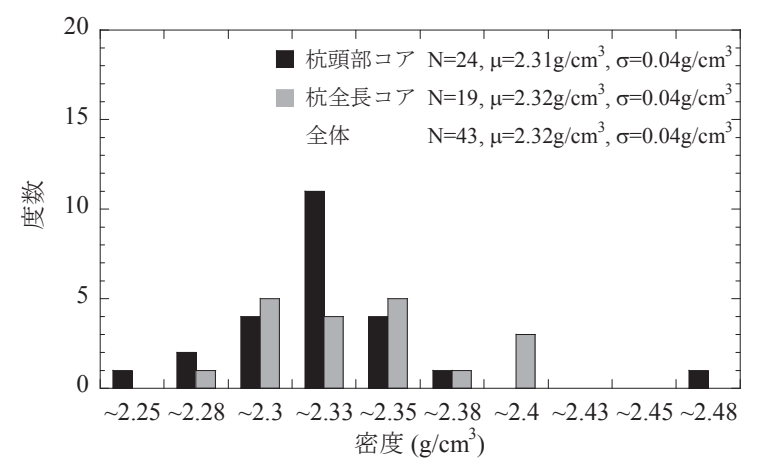

図 10 密度の度数分布

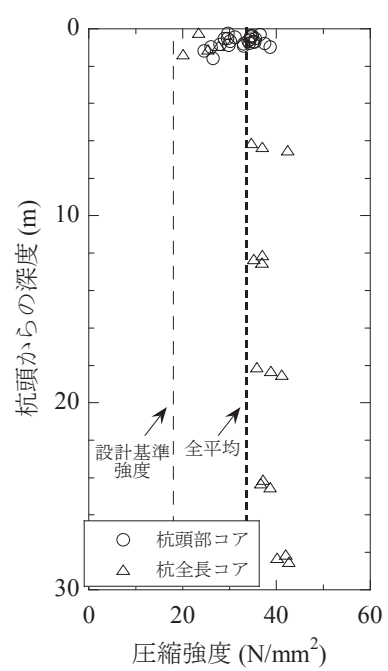

図 11 圧縮強度の深度分布

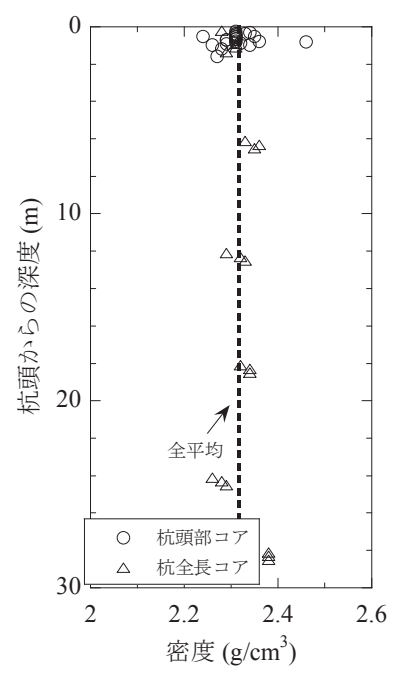

図 12 密度の深度分布

\section{2 杭の耐久性}

杭頭部コアと杭全長コアより採取した供試体を用いて試験を行い, 得られたコンクリートの圧縮強度と密度の度数分布を図 9〜10 に示 す。ここで, $N$ ：供試体数， $\mu$ : 平均值， $\sigma$ : 標準偏差である。図 9 の圧縮強度について, 度数の分布形状は概水山形であり, 杭頭部コ アの平均值 $\left(32.3 \mathrm{~N} / \mathrm{mm}^{2}\right)$ より杭全長コアの平均值 $\left(35.4 \mathrm{~N} / \mathrm{mm}^{2}\right)$ の方が やや大きい。供試体全体の圧縮強度の平均值は $33.7 \mathrm{~N} / \mathrm{mm}^{2}$, 構造強 度 ${ }^{9)}$ (平均值一 $0.5 \times$ 標準偏差) は $31.1 \mathrm{~N} / \mathrm{mm}^{2}$ であり，いずれも設計基 準強度 $\mathrm{Fc}\left(18 \mathrm{~N} / \mathrm{mm}^{2}\right)$ より十分大きい。図 10 の密度について, 度数の 分布形状は概数山形であり, 杭頭部コアと杭全長コアで平均值や標 準偏差にほとんど差は無い。

さらに，コンクリートの圧縮強度と密度の深度分布を図 $11 \sim 12$ に示す。図の縦軸は杭頭からの深度である。図 11 より, 杭頭の圧縮 強度は軸部や杭先端に比心゙小さく, ばらつきも大きい。これは, 地 下水位の変動により杭頭ではコンクリートの養生条件が変化するた めと考えられる。また, 杭先端の圧縮強度と密度は杭頭や軸部に比 べ若干大きいが, これは, 自重によりコンクリート内部の余剩水が 排出され，緻密な構造となるためと考えられる。

続いて, 杭頭部で採取した供試体を用いて試験を行い, 得られた コンクリートの中性化深さの度数分布を図 13 に示す。図より, 度数 の分布形状は概ね山形であり, 平均值 $\mu$ は $9.5 \mathrm{~mm}$, 標準偏差的 $3.7 \mathrm{~mm}$ であり, 設計かぶり厚より十分小さい。さらに, 中性化深さと経過

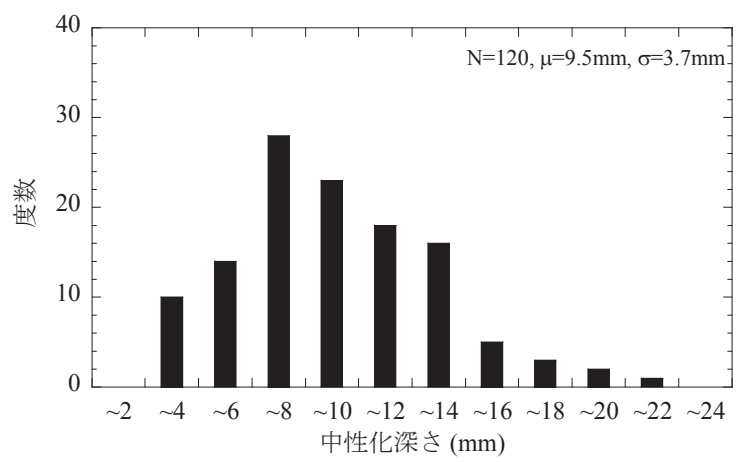

図 13 中性化深さの度数分布

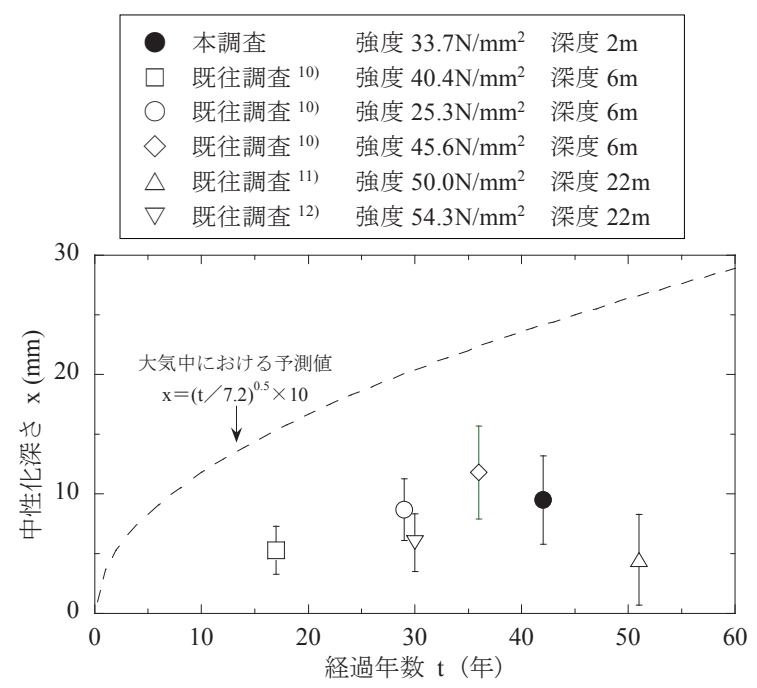

図 14 中性化深さと経過年数 
年数の関係について, 既往の調查結果 $\left.{ }^{10)} \sim 12\right)$ と比較して図 14 に示す。 $\mu \pm 1 \sigma$ 範囲を示しており, 大気中における中性化深さの進展予測 式(式(1) $)^{13)}$ による值も併せて示している。

$$
t=\frac{7.2}{R^{2}(4.6 \cdot w-1.76)^{2}} \cdot x^{2}
$$

ここで, $t$ : 深さ $\mathrm{x}$ まで中性化する期間 (年, 経過年数に相当), $\mathrm{x}$ : 中性化深さ $(\mathrm{cm}), \mathrm{w}$ : 水セメント比 (60\%を想定), $\mathrm{R}$ : 中性化率 (普通 ポルトランドセメントの使用を想定して $\mathrm{R}=1)$ である。本調査の中性 化深さは，大気中における予測值 $(24.2 \mathrm{~mm})$ に比べ小さく，その 4 割 程度である。また，既往の調查結果と比較して同程度であるが，既 往調査よりも地表に近い杭頭位置で供試体を採取しており，地下水 位の変動により中性化が進行しやすいことを考えると，むしろ良好 な結果である。また, 鉄筋引張試験により得られた降伏点, 引張強 さ，伸びは，全供試体で JIS 規格值 ${ }^{14)}$ を上回る結果であった。

\section{3 杭の支持層到達}

施工杭長の確認のため実施した磁気探査結果を図 15 に示す。図中 には，杭全長コアボーリングにより杭体を貫通して確認した杭先端 深度 (GL-31.9m) を併せて示している。図より, 得られた磁気探査波 形は GL-10m から GL-30m まであまり変化しないが, GL-30m を超える と急変し, それ以深で再び変化しなくなる。これは, 杭先端より梁 い位置では帯磁した鉄筋が無くなり, 磁場に変化が生じるためであ る。磁気探查結果より推定した杭先端深度は GL-31.9m であり, 杭体 貫通により確認した深度と一致していた。なお，地表近くの波形は 大きく乱れているが, これは探查対象の杭以外に, 調查のため地表 に設置した仮設ステージや資機材, 表層土の崩壊防止のため挿入し た鋼管も帯磁しているためと考えられる。

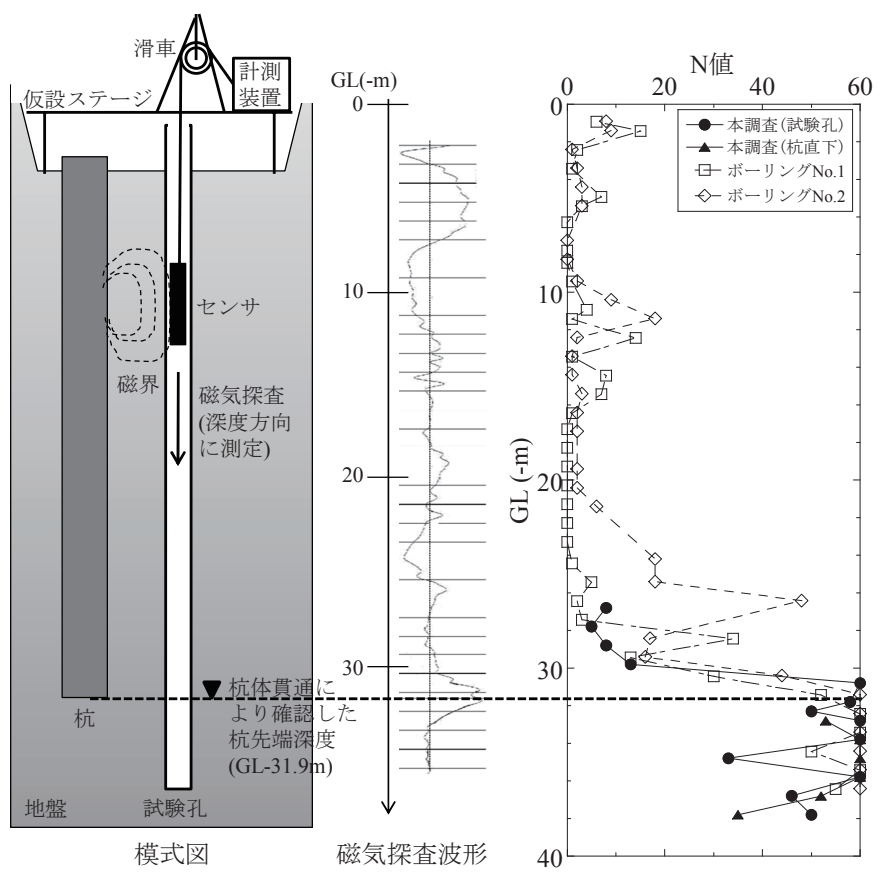

図 15 磁気探査結果
図 16 標準貫入試験結果
続いて, 杭支持層の深度を確認するため, 磁気探査用の試験孔と 貫通後の杭直下で実施した標準貫入試験結果を図 16 に示す。図中に は, 敷地内で実施した標準貫入試験結果 (ボーリング No. 1, 2, 図 1 に地点を記載) と, 杭体貫通により確認した杭先端深度を併せて示し ている。図より，N 值が 50 以上となる杭支持層の深度は GL-30. 8m であり，設計通り杭は支持層に到達していることを確認した。

\section{5. まとめ}

大型物流施設の建替えにあたり，次世代の環境配慮型建築として 既存杭を利用した建物を計画し，杭の健全性・耐久性・支持層到達 の調查を実施した。健全性について, 杭径や配筋状況が設計通りで あり，杭のひび割れについても問題なく，必要な性能を確保出来る ことを確認出来た。また，その際用いた筆者らの提案手法による評 価結果は, 従来手法と同等の結果を与えた。耐久性について, 圧縮 強度は設計值より十分大きく, 中性化深さは設計かぶり厚より十分 小さいことから，品質は良好であると確認出来た。支持層到達につ いて，杭体を貫通するコアボーリング調査により確認した杭先端深 度と，標準貫入試験により確認した杭支持層の深度を比較すること で，支持層への到達を確認できた。また，磁気探査により推定した 杭先端深度は杭体貫通により確認した深度と一致し，有効性を確認 できた。本報告が既存杭の利用促進の一助となれば幸いである。

最後に, 本調查を実施するにあたり, 多大な御協力を頂きました 工事事務所ならびに関係各位に心から謝意を表します。

\section{参考文献}

1) 建設業協会 : 既存杭利用の手引き，2003.2

2) 構造法令研究会 [編]：既存杭等再使用の設計マニュアル(案)，2008

3) 掛谷誠, 宮田章 : 都市部における地上構造物解体中の既存杭調査, 日本建 築学会大会学術講演梗概集, pp. 469-470, 2013.7

4) 勝二理智, 藤森健史 : 弾性波探査試験に基づく杭健全性の合理的評価法, 日本建築学会構造系論文集，Vol.81，No. 720，pp. 271-280，2016.2

5) 建設省土木研究所ほか : インティグリティ試験を用いた橋梁基礎の損傷調 査法マニュアル(案), 1999.3

6) 建設省土木研究所ほか：磁気探査を用いた橋梁基礎の形状調査法マニュア ル(案)，1999.3

7) 日本基礎建設協会 : 場所打ちコンクリート杭の施工と管理, pp. 134, 2009 8) 近藤次郎，宮崎祐助，芳賀孝成，崎本純治：打撃反射波による杭の形状推 定手法の研究，大林組技術研究所報，No. 39, pp. 21-26, 1989

9) 東京都都市計画局編 : 建築物の耐震診断システムマニュアル 鉄筋コンク リート，pp. 89，1990

10) 椿原康則, 山田毅, 山下清 : 場所打ちコンクリート杭の中性化調査例, 日 本建築学会大会学術講演梗概集 B-1, pp. 563-564, 2003.7

11) 石井雄輔, 西山高士, 山下清, 桑原文夫, 若井修一: 昭和 30 年代に築造 されたベノト杭の掘出し調査 その 1 2, 日本建築学会大会学術講演梗概 集 B-1，pp. 405-408，2012.9

12) 児島理士，勝二理智，藤井達，奥村豪悠，若井修一，青木雅路：築造後 30 年の場所打ちコンクリート杭の掘出し調査 その $1 \sim 2$, 日本建築学会大 会学術講演梗概集，pp. 565-568，2017.7

13) 岸谷孝一：鉄筋コンクリートの耐久性，鹿島出版社，1963

14）日本工業規格, JIS G 3112 鉄筋コンクリート用棒鋼

[2018 年 1 月 4 日原稿受理 2018 年 4 月 11 日採用決定］ 